\title{
Impact of crop rotations on optimal selection of conservation practices for water quality protection
}

\author{
S.S. Rabotyagov, M.K. Jha, and T. Campbell
}

\begin{abstract}
This research integrates modern multiobjective optimization tools, water quality modeling capability, and data on costs of implementing conservation practices to develop a tradeoff frontier of cost-efficient nonpoint source pollution reduction solutions, which can be used to derive the watershed-level pollution abatement cost curve. Farmers' decisions, both on the intensive and the extensive margin, are likely to affect the shape of the tradeoff frontier as well as the mix of conservation practices selected for achievement of given nutrient reduction goals. In this paper, we wish to explore the consequences of changes in the cropping practices on the intensive margin and changes in the amount of cropland on the extensive margin on the baseline water quality as well as the shape of the tradeoff frontier and the mix of conservation practices. An empirical application focuses on a typical Midwestern agricultural watershed, Squaw Creek watershed in central Iowa. Using detailed crop production budgets, we follow Secchi and Babcock (2007) to demonstrate an alternative land-use scenario, which could arise from recently observed changes in crop prices and production costs. We find that the change in cropping practices effects direct changes in the shape of the tradeoff frontier and the mix and location of conservation practices selected to achieve particular nutrient loading reductions. In particular, we find that a potential shift to more corn (Zea mays L.)-intensive crop rotations and an increase in the amount of cropland in the watershed may lead to increased loadings of both nitrate and phosphorus and that additional conservation investments are required to maintain water quality gains achieved under the baseline (historic) cropping practices. In terms of conservation practices selected, the optimal placement of terraces appears robust to the changes in crop rotations and amount of cropland in the alternative land-use scenario.
\end{abstract}

Key words: conservation practices—crop choice—evolutionary algorithm—water quality

\begin{abstract}
Changes in crop rotations as a result of farmer responses to market incentives are likely to impact both the baseline water quality and the set of conservation practices optimally selected for leastcost improvements in water quality. This work provides a framework for developing optimal tradeoffs between nutrient loadings and conservation investments, as well as spatially explicit, least-cost conservation practice selection plans in the presence of crop rotation changes. An empirical application focuses on a typical Midwestern agricultural watershed, Squaw Creek watershed in central Iowa.

Conservation practices, both involving retirement of land from agricultural pro-
\end{abstract}

primary importance. However, in nonpoint source water pollution problems, the complex biophysical relationships that connect human actions to eventual environmental outcomes make solving for cost-efficient allocations of abatement activities across space a challenging task. This research integrates multiobjective optimization tools, water quality modeling capability, and data on costs of implementing conservation practices to develop a cost-efficient tradeoff frontier for nonpoint source pollution reduction, which given baseline water quality, can be interpreted as a watershed-level pollution abatement cost curve.

We note that a particular tradeoff frontier invariably depends on the land use in a watershed. In particular, farmers' decisions both on the intensive and the extensive margin are likely to affect the shape of the tradeoff frontier as well as the mix of conservation practices selected for achievement of given nutrient reduction goals. In this paper, we wish to explore the consequences of changes in the cropping practices on the intensive margin and changes in the amount of cropland on the extensive margin on the baseline water quality as well as the shape of the efficient tradeoff frontier and the mix and spatial distribution of conservation practices.

We use Squaw Creek watershed in Jasper County, Iowa, as a demonstration. Recent years have seen dramatic swings in the price of corn (Zea mays L.) and soybeans (Glycine $\max$ [L.] Merr.). Using detailed crop production budgets, we follow Secchi and Babcock (2007) to construct an alternative land-use scenario in which farmers adjust to changes in crop prices and production costs by either changing crop rotations or bringing (removing) marginal land into (from) production. We find that the change in cropping practices effects strong changes in the shape of the efficient tradeoff frontier and the mix of conservation practices selected to achieve particular nutrient loading reductions. In particular, we find that a shift to more corn-

Sergey S. Rabotyagov is an assistant professor at the School of Forest Resources, University of Washington, Seattle, Washington. Manoj K. Jha is an assistant professor in the Civil Engineering Department at North Carolina A\&T State University, Greensboro, North Carolina. Todd Campbell is a systems analyst at the Center for Agricultural and Rural Development, Department of Economics, lowa State University, Ames, lowa. 
intensive crop rotations and an increase in the amount of cropland in the watershed leads to increased loadings of both nitrate and $\mathrm{P}$ and that additional conservation investments are required to maintain water quality gains achieved under the baseline (historic) cropping practices.

\section{Materials and Methods}

Conceptual Framework. Suppose that a set of field-level conservation practices can be undertaken to improve water quality in the watershed, with multiple practices possible for each field. We denote a particular configuration of conservation practices on all fields of the watershed as $X$.

The environmental impact of $X$ is denoted as $Y$, where $Y$ is a vector with $N$ elements, i.e., $\left.Y=\gamma^{1}, \gamma^{2}, \ldots \ldots \gamma^{N}\right)$. Each element represents one environmental indicator; for example, $y^{n}$ can be a pollutant (nitrogen [N], P, etc.) loading at the watershed outlet or some index of local water quality indicators. The relationship between $Y$ and $X$ is denoted as

$y^{n}=f^{n}(X ; Z)$,

for all $n=1,2, \ldots \ldots N$, where $Z$ is a set of factors that affect $y^{n}$ but are not part of the conservation practices set such as soil and land characteristics, cropping patterns, climate, etc. Potentially, $Z$ represents a collection of all the land and climate characteristics for each field in each watershed.

Denote $T$ as the set of all $(X, Y)$ combinations that are technically feasible given the existing state of conservation technology and are subject to the physical constraints imposed by the environmental processes. The cost of a conservation practice configuration is denoted by $c(X)$. In general, different conservation practice configurations result in different costs and different environmental outcomes. Thus, one important goal of watershed management is to achieve an efficient tradeoff of costs, $c(X)$, and pollution reductions represented by $Y$. These tradeoffs can be identified through the following multiobjective optimization problem:

$\operatorname{minimize}\left[c(X), \gamma^{1}, \gamma^{2}, \ldots \ldots \gamma^{N}\right]$

such that $(X, Y) \in T$.

The set of solutions to the problem above consists of all conservation practice configurations that are Pareto-optimal. $X$ is Pareto-optimal if there is no $\left(X^{\prime}, Y^{\prime}\right) \in T$ such that $f^{n}\left(X^{\prime}\right) \leq f^{n}(X)$ and $c\left(X^{\prime}\right) \leq c(X)$, for all $n \in\{1,2, \ldots, N\}$, and such $m \in\{1,2, \ldots, N\}$, such that $f^{m}\left(X^{\prime}\right)<f^{m}(X)$ or $c\left(X^{\prime}\right)<c(X)$. In other words, the solutions to the problem above together make up the efficient tradeoff frontier given $T$ and $c(X)$.

Efficient Nonpoint Source Pollution Control and the Optimization Algorithm. In practice, studying the least-cost solution in the watershed context is fraught with difficulty. The effectiveness of a given conservation practice on a given field depends on the placement of other conservation practices, on cropping systems in the watershed, and the physical characteristics of the watershed location and the watershed itself. In other words, off-site impacts of land use on any parcel in a watershed tend to be endogenous to land-use choices on other parcels of the watershed. However, earlier studies on the economics of water pollution control on watershed scale essentially followed Montgomery's (1972) conceptual model of fixed, exogenous, pollution delivery coefficients. Studies by Carpentier et al. (1998), Kramer et al. (1984), and Ribaudo (1986, 1989) assume that off-site impacts can be accurately described as a proportion of on-site pollution generated. Given such assumptions, it is straightforward to solve for cost-efficient allocations of pollution abatement using calculus-based constrained optimization techniques. However, such approaches are unlikely to be representative of the actual pollution process in a watershed, where the impacts of polluting sources are often determined by complex biophysical processes. In particular, pollutant loadings discharged from specific source areas can be impacted by ongoing in-stream processes, including deposition or assimilation along the waterway and additional inputs through atmospheric deposition. Physically based, spatially distributed hydrologic simulation models allow for a greater degree of realism in terms of process representation but usually require a shift to noncalculus-based optimization approaches and a development of a simulation-optimization framework where the model becomes an integral part of optimization.

Conceptually, if one could analyze all feasible watershed configurations and their costs and water quality outcomes, picking cost-efficient solutions would be trivial. However, for any realistic watershed problem, a brute force approach is infeasible.
Recently, several researchers found a useful optimization tool, which appears to be able to deal with the combinatorial nature of a watershed simulation-optimization problem. Evolutionary algorithms (EA) provide one systematic way for searching through large search spaces. Evolutionary algorithms aim to mimic the process of biological evolution, which in the words of Mitchell (1996), "in effect, is a method of searching for solutions among an enormous amount of possibilities." Evolutionary algorithms work with populations of candidate solutions iteratively applying stochastic operators of selection, recombination, and mutation in the hope of finding improvements with respect to the optimization objectives (loosely borrowing such operators and terminology from the theory of biological evolution). In general, EAs belong to a class of stochastic optimization methods and are well suited for approximating solutions to complex combinatorial problems (see, e.g., Deb 2001; Forrest 1993). Optimization methods falling under the broader EA classification have been successfully applied to integrated watershed modeling systems (Srivastava et al. 2002; Veith et al. 2003; Bekele and Nicklow 2005; Lant et al. 2005; Muleta and Nicklow 2005; Arabi et al. 2006; Whittaker et al. 2007; Jha et al. forthcoming; Rabotyagov et al. 2010). To our knowledge, this is the first study to investigate the impact of land-use changes exogenous to optimization on the efficient frontier of tradeoffs between multiple water quality objectives $(\mathrm{N}$ and $\mathrm{P})$ and the cost of conservation investments. In this application, we use a variant of a multiobjective evolutionary algorithm SPEA2 (Zitzler et al. 2002) to search for the frontiers of cost-efficient allocation of conservation practices across the watershed in a single optimization run.

As pointed out by a reviewer of this paper, traditional optimization techniques could indeed be used, but the combinatorial nature of the problem often limits the size of the problem undertaken (as in Khanna et al. [2003], where only a narrow band of land adjacent to stream was a part of the optimization). Also, since these methods cannot directly integrate the watershed model into optimization, some of the useful features of the process model might be lost. Finally, EA (a class of global optimization methods) are in many cases easier to implement than other optimization techniques and are particularly 


\section{Table 1}

Glossary of the evolutionary optimization implementation.

\begin{tabular}{|c|c|c|}
\hline $\begin{array}{l}\text { Evolutionary } \\
\text { algorithm term }\end{array}$ & Interpretation & $\begin{array}{l}\text { Corresponding term } \\
\text { in a watershed } \\
\text { application }\end{array}$ \\
\hline Individual & Candidate solution vector & $\begin{array}{l}\text { A particular watershed } \\
\text { configuration, list of HRUs }\end{array}$ \\
\hline Gene & $\begin{array}{l}\text { Element of a candidate } \\
\text { solution vector }\end{array}$ & $\begin{array}{l}\text { A spatial decision- } \\
\text { making unit (HRU) }\end{array}$ \\
\hline Allele set & $\begin{array}{l}\text { A set of values that an } \\
\text { element of a candidate } \\
\text { solution can take }\end{array}$ & $\begin{array}{l}\text { A set of conservation practice } \\
\text { options which can be } \\
\text { implemented on an HRU }\end{array}$ \\
\hline Allele & $\begin{array}{l}\text { A value of an element of a } \\
\text { candidate solution; member } \\
\text { of the allele set }\end{array}$ & $\begin{array}{l}\text { A particular conservation } \\
\text { practice combination which } \\
\text { can be assigned to an HRU }\end{array}$ \\
\hline Population & $\begin{array}{l}\text { A collection of } \\
\text { candidate solutions }\end{array}$ & $\begin{array}{l}\text { A collection of distinct } \\
\text { watershed configurations }\end{array}$ \\
\hline
\end{tabular}

Note: HRUs = hydrologic response units. are important. Changes to the baseline water quality (in the absence of any additional conservation practice investments) have a direct environmental impact, and measuring and understanding such changes is important to policymakers and environmental managers. Changes in the shape of the tradeoff frontier inform us of the nature of the new constraints imposed by land-use changes. Figure 1 illustrates the two types of changes for the case of a single water pollutant (for example, N). Curve ECA represents the tradeoff frontier under the baseline (historic) land use, while curve DB represents the tradeoff frontier under the alternative land use. Point A represents the baseline water quality condition under the historic land use, while point $\mathrm{B}$ represents a baseline water quality condition under the alternative land use. In this example, land-use change contributes to higher $\mathrm{N}$ loadings. As drawn, land-use changes make the achievement of historic $\mathrm{N}$ loadings more expensive (by the dollar amount CD at the nitrogen level $\mathrm{N}_{\text {intermediate }}$ ) and make the achievement of some nitrogen levels not feasible (level $\mathrm{N}_{\text {low }}$ ).

Figure 1 demonstrates an example of a land-use change that is detrimental to water quality. Of course, land-use changes may prove to be beneficial to water quality as well. The tradeoff frontier obtained under the alternative land use could be located (fully or in part) closer to the origin in the pollutioncost space than the tradeoff frontier obtained under the baseline land use.

In figure 1, distance CD represents the additional dollar amount invested in conservation practices that ensures that the $\mathrm{N}$ level $\mathrm{N}_{\text {intermediate }}$ is achieved under the alternative land use. This amount accurately represents the cost of land-use change for this particular level of nutrient loadings for the case where the mix and location of conservation practices can be costlessly adjusted. In practice, however, it might be the case that the conservation mix described by $\mathrm{C}$ is fixed (perhaps due to a contract signed with farmers), and when the land use changes, this particular set of conservation practices will then act as a constraint on the selection of least cost practices under the alternative land use. In that case, the dollar cost of land-use change (at $\mathrm{N}$ level $\mathrm{N}_{\text {intermediate }}$ ) will be greater or equal to CD.

Application. Squaw Creek watershed in Jasper County, Iowa, is selected for this application. The watershed is located in the Southern Iowa Drift Plain landscape region, an tion practices that could be applied to each HRU. An individual describes a particular
Impact of Land-Use Change on the Tradeoff Frontiers. Land-use changes are likely to affect both the baseline water quality and also to change the shape of the tradeoff frontier itself. Both types of changes 


\section{Table 2}

Conservation practice options (allele set).

\begin{tabular}{|c|c|c|}
\hline Allele number & Allele description & Cost per acre (dollars $\left.\mathrm{y}^{-1}\right)$ \\
\hline 1 & Conventional till & 0 \\
\hline 2 & Ridge-till & 0 \\
\hline 3 & Mulch-till & 3.4 \\
\hline 4 & No-till & 6.9 \\
\hline 5 & CT + contour & 6.6 \\
\hline 6 & RT + contour & 6.6 \\
\hline 7 & $\mathrm{MT}+$ contour & 10.1 \\
\hline 8 & NT + contour & 13.5 \\
\hline 9 & CT + grassed waterway & 5.6 \\
\hline 10 & RT + grassed waterway & 5.6 \\
\hline 11 & MT + grassed waterway & 9.1 \\
\hline 12 & NT + grassed waterway & 12.5 \\
\hline 13 & $\mathrm{CT}+$ terraced & 48.3 \\
\hline 14 & $\mathrm{RT}+$ terraced & 48.3 \\
\hline 15 & MT + terraced & 51.7 \\
\hline 16 & NT + terraced & 55.2 \\
\hline 17 & $\mathrm{CT}+\mathrm{RF}$ & 39.4 \\
\hline 18 & $\mathrm{RT}+\mathrm{RF}$ & 39.4 \\
\hline 19 & $\mathrm{MT}+\mathrm{RF}$ & 44.8 \\
\hline 20 & $\mathrm{NT}+\mathrm{RF}$ & 48.3 \\
\hline 21 & $\mathrm{CT}+$ contour + RF & 48.0 \\
\hline 22 & $\mathrm{RT}+$ contour + RF & 48.0 \\
\hline 23 & $\mathrm{MT}+$ contour + RF & 51.4 \\
\hline 24 & $\mathrm{NT}+$ contour + RF & 54.9 \\
\hline 25 & $\mathrm{CT}+$ grassed waterway $+\mathrm{RF}$ & 47.0 \\
\hline 26 & $\mathrm{RT}+$ grassed waterway + RF & 47.0 \\
\hline 27 & $\mathrm{MT}+$ grassed waterway + RF & 50.4 \\
\hline 28 & NT + grassed waterway + RF & 53.9 \\
\hline 29 & $\mathrm{CT}+$ terraced $+\mathrm{RF}$ & 89.6 \\
\hline 30 & $\mathrm{RT}+$ terraced + RF & 89.6 \\
\hline 31 & $\mathrm{MT}+$ terraced + RF & 93.1 \\
\hline 32 & $\mathrm{NT}+$ terraced + RF & 96.5 \\
\hline 33 & Land retirement & 149.8 \\
\hline
\end{tabular}

Notes: $\mathrm{CT}=$ conventional till. $\mathrm{RT}=$ ridge-till. $\mathrm{MT}=$ mulch-till. $\mathrm{NT}=$ no-till. $\mathrm{RF}=$ reduced fertilizer. In executing the assignment of hydrologic response units to a particular member of the allele set, a constraint that guaranteed that the new set of conservation practices is "no worse" than the baseline is added. In terms of practices, contours can be replaced by a grassed waterway, and grassed waterway can be replaced by a terrace. However, the reversals are not allowed. For example, a grassed waterway cannot be replaced by contour farming. If contour is observed in the baseline, it can be replaced by grassed waterways or terraces. Grassed waterways observed in the baseline can be replaced by terraces. Terraces observed in the baseline cannot be replaced. Similarly, tillage practices are ranked by the amount of plant residue left on the field: conventional till, ridge-till, mulch-till, and no-till (CT, RT, MT, and NT, respectively). For example, if an hydrologic response unit is observed to contain a grassed waterway with mulch-till, it could not be replaced by any options containing CT or RT, or contours. Also, if in the progression of the algorithm, a conservation practice is to be removed, extra care is taken to only revert as far back as the baseline set of conservation practices allows. area characterized by steeply rolling hills and well-developed drainage. Soils consist mainly of silty clay loams, silt loams, or clay loams formed in loess and pre-Illinoian till overlying Pennsylvanian Cherokee Group shale, limestone, sandstone, and coal (Schilling et al. 2006). The study area is in a humid, continental region with average annual precipitation of 750 $\mathrm{mm}$ (29.53 in). Schilling et al. (2006) and Jha et al. (2010) provide an extensive background on watershed characteristics, as well as hydrologic, water quality, and biological monitoring data. Located in the Southern Iowa Drift Plain, the Squaw Creek watershed is a typical area of row-crop agriculture.

Water Quality Model. The SWAT (Soil and Water Assessment Tool) model (Arnold et al. 1998; Arnold and Forher 2005) is a conceptual, physically based, long-term, continuous watershed-scale simulation model. In SWAT, a watershed is divided into multiple subwatersheds, which are further subdivided into HRUs that consist of homogeneous land use, management, and soil characteristics. Streamflow generation, sediment yield, and nonpoint source loadings from each HRU are summed, and the resulting loads are routed through channels, ponds, and/or reservoirs to the watershed outlet. Key components of SWAT include hydrology, plant growth, erosion, nutrient transport and transformation, pesticide transport, and management practices. Outputs provided by SWAT include streamflow and in-stream loading or concentration estimates of sediment, organic $\mathrm{N}$, nitratenitrogen $\left(\mathrm{NO}_{3}-\mathrm{N}\right)$, organic $\mathrm{P}$, soluble $\mathrm{P}$, and pesticides. Previous applications of SWAT for streamflow and/or pollutant loadings have compared favorably with measured data for a variety of watershed scales (e.g., Arnold et al. 1999, 2000; Borah and Bera 2004; Jayakrishnan et al. 2005; Gassman et al. 2007).

Baseline and Alternative Land Uses. Baseline land use is based on 2005 field-level data (Schilling et al. 2006). Figure 2a and table 3 depict the baseline land use in terms of crop rotations. As in much of Iowa, in 2005 Squaw Creek watershed was farmed under a corn-soybean rotation. The total cropland area of the watershed was $35.53 \mathrm{~km}^{2}(8,780$ ac). Information on observed tillage practices and existing conservation practices is also collected (Schilling et al. 2006) and is used in building the baseline SWAT run. Spatially referenced field-level data on crop choices and conservation practices were used to construct the HRUs. Spatial units in the same 


\section{Figure 1}

Effects of land-use changes on the efficient tradeoff frontier.

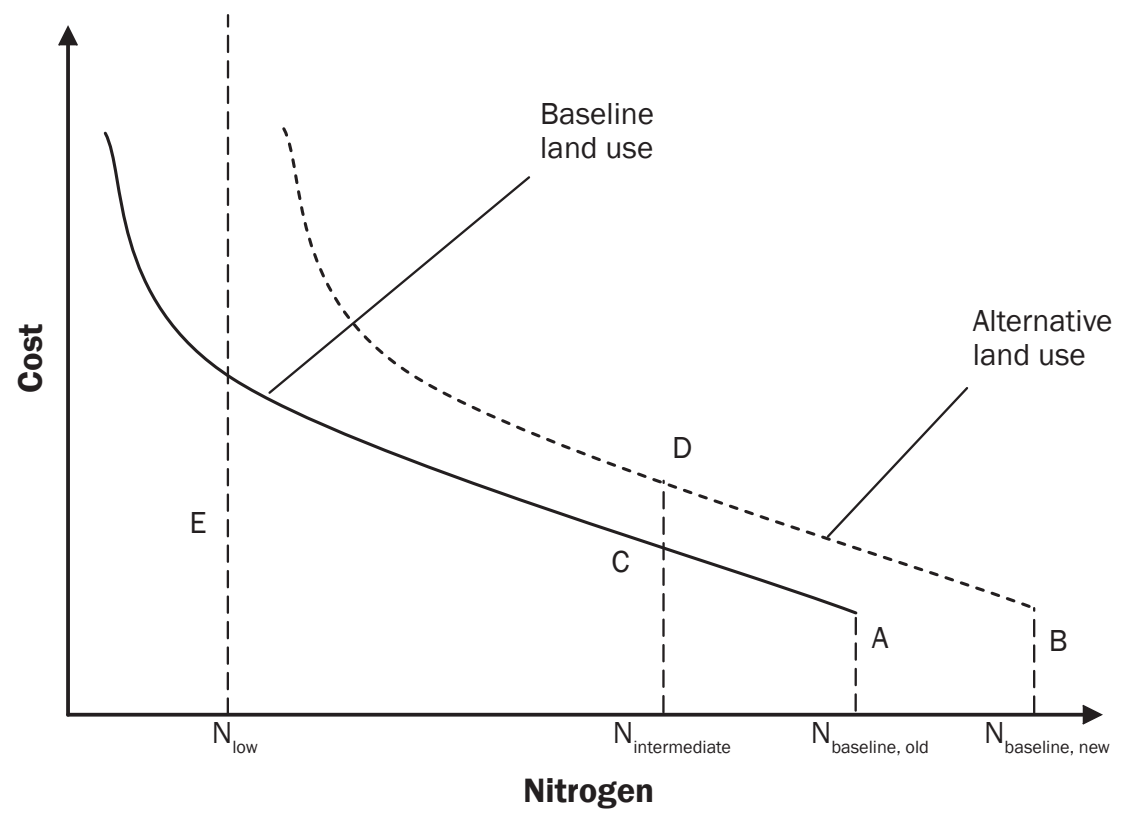

Note: $\mathrm{N}=$ nitrogen. subbasin, slope and soil class, crop pattern, and conservation practice recorded form an HRU. In all, 1,213 HRUs are created for baseline land use, forming a list of decisionmaking units for optimization.

For creating an alternative land-use pattern, we use the detailed crop production budgets (described in Secchi and Babcock 2007). For each field in our data, we use the crop production budgets to predict a profitmaximizing crop pattern, given a change in crop prices. Using recent (May 2008) futures prices for corn and soybeans $(\$ 5.9$ and $\$ 11.8$ $\mathrm{bu}^{-1}\left[\$ 167.4\right.$ and $\left.\$ 334.9 \mathrm{~m}^{-3}\right]$, respectively), we apply the methodology of Secchi et al. to select the two-year rotation that maximizes net returns for a particular field, given the soil's corn suitability rating. (Long-term price projections based on FAPRI [2007] general equilibrium modeling were also used, but the resulting land use was not sufficiently different from the current futures prices to warrant a separate discussion.) Baseline (observed) 2005 land-use information was used to complete the crop rotations. Information on the Conservation Reserve Program (CRP) rental

\section{Table 3}

Crop rotations and tillage systems in the watershed.

\begin{tabular}{lcccc}
\hline Cropping practice & $\begin{array}{l}\text { Baseline } \\
\text { land use } \\
\mathbf{( k m}^{\mathbf{2}}\end{array}$ & $\begin{array}{l}\text { Cropland } \\
\mathbf{( \% )}\end{array}$ & $\begin{array}{l}\text { Alternative } \\
\text { land use } \\
\mathbf{( k m}^{\mathbf{2}}\end{array}$ & $\begin{array}{l}\boldsymbol{l}_{\text {Cropland }} \\
\mathbf{( \% )}\end{array}$ \\
\hline Crop rotations & & & & \\
\hline Continuous corn (C-C) & 0.0 & 0.00 & 20.6 & 0.52 \\
Corn-soybeans (C-S) & 35.2 & 0.99 & 3.8 & 0.10 \\
Corn-corn-soybeans (S-C-C) & 0.1 & 0.00 & 15.5 & 0.39 \\
Corn-corn-oats/Alfalfa-alfalfa & & & & \\
(C-C-O/A-A) & 0.2 & 0.01 & 0.1 & 0.00 \\
\hline Tillage system & & & & \\
\hline Conventional till (CT) & 2.2 & 0.06 & 34.4 & 0.86 \\
Mulch-till (MT) & 27.6 & 0.78 & 5.3 & 0.13 \\
No-till (NT) & 5.8 & 0.16 & 0.3 & 0.01 \\
& & & & \\
\end{tabular}

rates (Secchi et al.2007) is used to determine whether changes occur on the extensive margin, that is, whether a field observed to be in CRP in the baseline enter crop production in the event of crop price changes. Essentially, this assumes a zero cost of breaking the CRP contract. Given that CRP contracts have been observed to be broken, we choose to highlight the potential extensive margin impacts of crop price changes, although we do anticipate that in reality, such conversion would not occur instantaneously. Not surprisingly, higher crop prices make more marginal land profitable, and the cropland area of the watershed rises to $39.99 \mathrm{~km}^{2}$ $(9,884 \mathrm{ac})$, a $13 \%$ increase in the cropland area. In the alternative scenario, dominant crop rotation changes from a corn-soybean rotation to a continuous corn cropping practice (figure 2).

In addition, the area of the watershed farmed using conventional tillage increases dramatically in the alternative land use, due to the increased cost of reported "yield drag" from conservation tillage techniques, especially under corn-heavy rotations (Secchi and Babcock 2007). Table 3 provides a breakdown of cropland use by crop rotation and tillage system. Having predicted crop choice using field-level data, HRUs are constructed for the alternative land-use scenario in the manner described above. In all, 1,206 HRUs are created for the alternative land-use scenario.

Water Quality Baselines. Using the baseline land-use information, the predicted alternative land-use information, as well as other inputs such as weather (a rain gage located at the mouth of the watershed [Jha et al. 2010] and a National Weather Service Cooperative Observer Program climate station [ISU 2009] provided precipitation and temperature data), soil (Soil Survey Geographic data [USDA 2008]), and topographic (5 m [16.4 ft] digital elevation model [USGS 2008]) data, two separate SWAT baselines were built. Using monitoring data on flow and nutrient loadings, the SWAT model was calibrated under the two different land-use scenarios.

Using the calibrated SWAT model, two distinct water quality baselines were established, one for the baseline land use and another for the alternative land use. Given that the alternative land use involves much more corn and much less conservation tillage, we expect the water quality impact of land-use change induced by high crop prices 


\section{Figure 2}

Baseline and alternative cropping patterns in the watershed. (a) Squaw Creek, baseline (2005) land use. (b) Squaw Creek, alternative land use under higher crop prices.

(a)

\section{Legend}

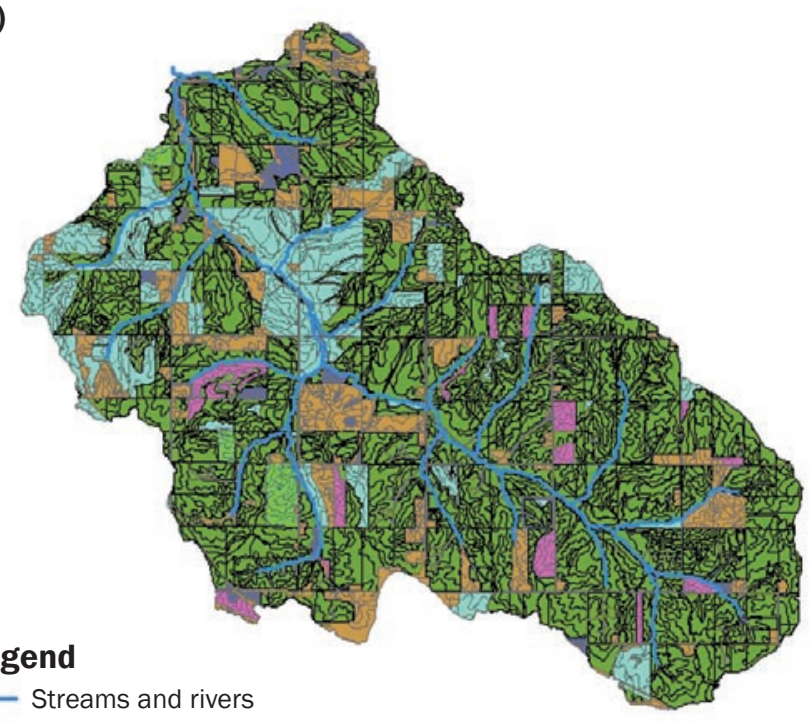

Rotations (historical crop prices)

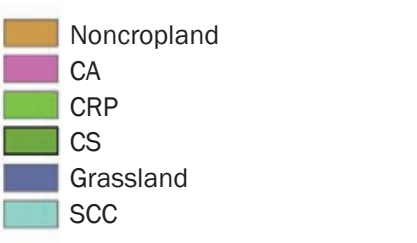

(b)

\section{Legend}

- Streams and rivers

\section{Rotations (current crop prices)}

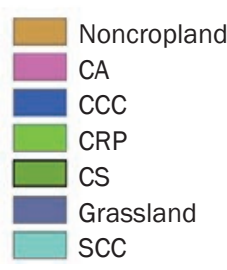

Notes: $\mathrm{CA}=$ corn-corn-oats/alfalfa-alfalfa rotation. CRP = Conservation Reserve Program. CS = corn-soybean rotation. SCC $=$ corn-corn-soybeans. $\mathrm{CCC}=$ continuous corn.

to be negative. Modeling results are consistent with our expectations. We find that the baseline land use yields a model-predicted average annual $\mathrm{NO}_{3}-\mathrm{N}$ loading of 70,530 $\mathrm{kg}(155,492 \mathrm{lb})$, while the alternative land use yields average annual $\mathrm{NO}_{3}-\mathrm{N}$ loading of $125,422 \mathrm{~kg}(276,508 \mathrm{lb})$, a $78 \%$ increase. This is plausible, as the area-weighted increase in $\mathrm{N}$ fertilizer application is expected to be about 66\% (baseline land-use modeling results are also reasonably close to the observed annual nitrate and $\mathrm{P}$ loadings reported by Schilling et al. [2006]). The model also predicts dramatic increases in total $\mathrm{P}$ loadings, with mean annual loadings increasing from 9,491 to $32,000 \mathrm{~kg} \mathrm{y}^{-1}\left(20,924\right.$ to $\left.70,548 \mathrm{lb} \mathrm{yr}^{-1}\right)$ as land-use changes to involve more corn production and less conservation tillage. Much of the increase is attributed by the model to the increase in the organic component of P.This, again, is plausible given the expected increase in soil erosion associated with switching to conventional tillage systems.
Optimization Algorithm Implementation. There are a number of abatement activities that individual farmers can undertake to reduce $\mathrm{N}$ and $\mathrm{P}$ loadings from their fields. Various in-field conservation practices include conservation tillage, buffer strips, grassed waterways, as well as complete retirement of land from crop production in favor of other uses. (The CRP is a very large, federally funded program that makes direct payments to farmers to remove their land from active production and instead plant trees or other perennial ground cover). In addition, $\mathrm{N}$ and $\mathrm{P}$ loadings can be directly controlled by reducing the amount of application of $\mathrm{N}$ and $\mathrm{P}$ fertilizer to the crop. In this study, we consider several in-field conservation practices, a reduction in $\mathrm{N}$ fertilizer application, and retirement of land from crop production. With the exception of land retirement, all other practices are modeled in conjunction with the cropping system assumed to be in place.

Furthermore, some conservation practices were observed to be a part of the baseline land use. In this application, the conservation practices observed in the baseline land use are preserved, while allowing the algorithm to change crop rotations and add other conservation practice options.

Table 2 presents the set of conservation practices in consideration for each HRU (allele set) used in this study. As discussed above, for the HRUs that were observed to have the relevant conservation practice in the baseline, the allele set was constrained (described in table 2). Reduced fertilizer in the table above refers to a $20 \%$ reduction in $\mathrm{N}$ fertilizer application. The allele set is constructed to take into account the fact that many of the practices considered are not mutually exclusive and can be implemented jointly on any given field.

The practices are simulated using the SWAT model. In particular, land retirement is modeled by assigning a permanent grass cover to the HRU, fertilizer reductions are modeled by reducing $\mathrm{N}$ fertilizer applications by $20 \%$ for all crop rotations where $\mathrm{N}$ fertil- 
izer is used, and the in-field practices (tillage, grassed waterways, contour farming, and terraces) are modeled by adjusting the SWAT model parameters as suggested by Arabi et al. (2007) and Secchi et al. (2007).

Detailed information on the costs of all the options is obtained from multiple sources. Cost estimates for terraces, no-till, and contouring are gathered from the USDA Natural Resources Conservation Service Web site (USDA NRCS 2007). The costs of grassed waterways are obtained from the CRP program office and are converted to a per acre protected, annualized basis using a $5 \%$ discount rate and a 20 -year useful life term, with the assumption (as in Secchi et al. [2007]), that $2 \%$ of an acre allocated to a grassed waterway protects the entire acre. The cost of $\mathrm{N}$ fertilizer reduction was estimated based on agronomic yield response data (Sawyer et al. 2006). Predicted yield reduction, multiplied by the price of corn, served as an approximation to the cost of reducing $\mathrm{N}$ fertilizer application (assumed $\mathrm{N}$ fertilizer application rate is $155.95 \mathrm{lb} \mathrm{ac}^{-1}$ [17.48 $\left.\left.\mathrm{Mg} \mathrm{km}^{2}\right]\right)$. For terraces, a 25-year useful life was assumed, and based on Kling et al. $(2005,2007)$, it was assumed that $166.67 \mathrm{ft}$ $(50.8 \mathrm{~m})$ of terrace protect one acre of cropland. The costs of land retirement are proxied by the state cash rental rates (Edwards and Smith 2007). (A legitimate question raised by one of the reviewers of this paper is that the opportunity costs of conservation practice adoption may change with the changes in output prices and production costs. Ideally, an econometric model of conservation practice adoption (e.g., Cooper and Keim 1996; Kurkalova et al. 2005; Lichtenberg 2004) would be estimated to provide estimates of the response of costs of conservation practice adoption to such changes. While incorporation of such modeling will improve the cost estimates and serve as a valuable extension of current work, the lack of farmer-level economic data left it outside of the feasible scope of this article).

The algorithm is initialized with a population of 50 individuals (watershed configurations). The initial population is seeded with an individual representing the baseline allocation of conservation practices and an individual representing a scenario of all cropland in the watershed retired from production (i.e., allele \#33). These individuals represent the boundary points on the tradeoff frontier: the baseline individual results in the lowest cost and highest nutrient loadings, while the "all cropland retired" individual results in the highest cost and lowest nutrient loadings. We further assist the algorithm in exploring the search space by including additional 32 individuals representing the uniform application of alleles \#1 through \#32 onto the entire cropland in the watershed. The rest of the initial population is generated by randomly assigning the cropland HRUs with one of the 33 alleles listed in table 2 (subject to the constraints indicated).

\section{Results and Discussion}

Three major components were integrated to arrive at the final modeling framework. The first component is the logical structure of a multiobjective evolutionary optimization algorithm, SPEA2 (Zitzler et al. 2002). The second component is a publicly available $\mathrm{C}++$ library of genetic algorithms, GALib, originally developed by Wall (1996), with the current version available online. The third component is the hydrologic model, SWAT2005, coupled with a Windows-based database control system, i_SWAT (CARD 2007) (Gassman et al. 2003). SPEA2 provides the fundamental multiobjective optimization logic, while GALib implements the evolutionary algorithm. Finally, SWAT and i_SWAT provide a way to model the different conservation practices considered in this paper and model their watershed-level environmental impacts. In every generation, GALib evaluates each new individual of the population, invoking i_SWAT and SWAT. i_SWAT reads the watershed data from an Microsoft Access database. Conservation practices specified for an individual are applied to the HRUs, SWAT input files are created, and SWAT is run. The results for $\mathrm{N}$ and $\mathrm{P}$ loadings at the watershed outlet and the costs of conservation practices are used to Pareto-compare individuals as described earlier and in Zitzler et al. (2002). Each land use is run for 200 generations, with each run taking about 19 hours to complete on a quad-core processor-equipped desktop computer. (Our experience indicates that results do not change in a meaningful fashion if the algorithm iterations are increased. As many as 1,000 iterations were performed.)

After the algorithm iterations are terminated, a set of surviving nondominated individuals represents the approximate tradeoff frontier. Since two nutrients are being considered simultaneously $\left(\mathrm{NO}_{3}-\mathrm{N}\right.$ and total $\mathrm{P}$ ), we obtain a three-dimensional tradeoff frontier. Two tradeoff frontiers are obtained, one corresponding to the baseline (historical) land use, and another one corresponding to the alternative land use. This allows us to obtain the empirical counterparts to the conceptual diagram in figure 1 of relative positions of the tradeoff frontiers under different land uses. Since both $\mathrm{N}$ and $\mathrm{P}$ are considered, we present both in figures 3 and 4.

As discussed earlier and as shown in is clear from figures 3 and 4, land-use change dramatically increases the baseline loadings of both nitrate and P. In that sense, this kind of land-use change is definitely detrimental to water quality. The change in the shape of the tradeoff frontier brought about by landuse change is clearly detrimental to water quality along the $\mathrm{P}$ dimension, as the frontier projection onto $\mathrm{P}$-cost space of the historical land-use tradeoff frontier lies below the projection of the alternative land-use tradeoff frontier for the majority of P levels. Not only is the land-use change costly in terms of the vertical distance between the $\mathrm{P}$-cost projections but land-use changes also increase the minimum feasible level of $\mathrm{P}$ levels. In this sense, the P-cost tradeoffs exhibit a pattern hypothesized in the conceptual diagram above for the level of nutrient $\mathrm{N}_{\text {low }}$.

A different picture emerges when we consider the tradeoff frontier projections onto the nitrate-cost space. In this case, we cannot claim that land-use change is always detrimental to the $\mathrm{N}$ dimension of water quality. In fact, the two projections seem to overlap in a way that suggests that for some $\mathrm{N}$ levels, the alternative land use decreases the cost of achieving $\mathrm{N}$ targets, while for other $\mathrm{N}$ levels, the opposite is true. Overall, the two tradeoff frontier projections appear to be quite close to each other (with the exception of the portion the alternative land-use tradeoff frontier that extends into larger $\mathrm{N}$ values).

Watershed Configurations for Specific Nutrient Reduction Targets. Each individual point on the tradeoff frontier prescribes a particular configuration of conservation practices for each decision-making unit (cropland HRU) in the watershed. To see which conservation practices are selected, we have to specify nutrient targets and then search the tradeoff frontier for individual configurations that meet the nutrient reduction criteria.

In the absence of a well-defined social preference relating nutrient loadings and 


\section{Figure 3}

Projections of the tradeoff frontier onto phosphorus-cost space.

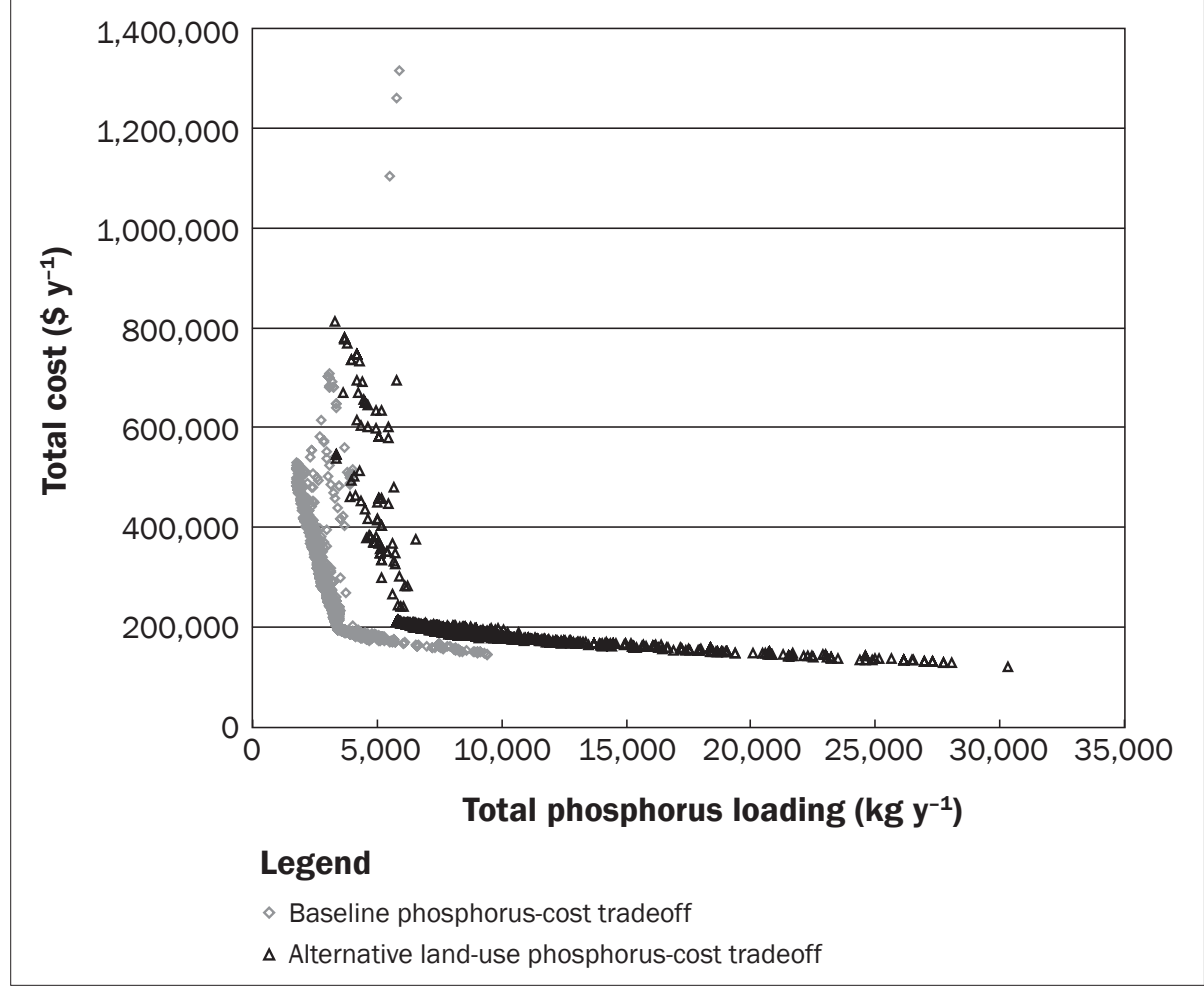

\section{Figure 4}

Projections of the tradeoff frontier onto nitrogen-cost space.

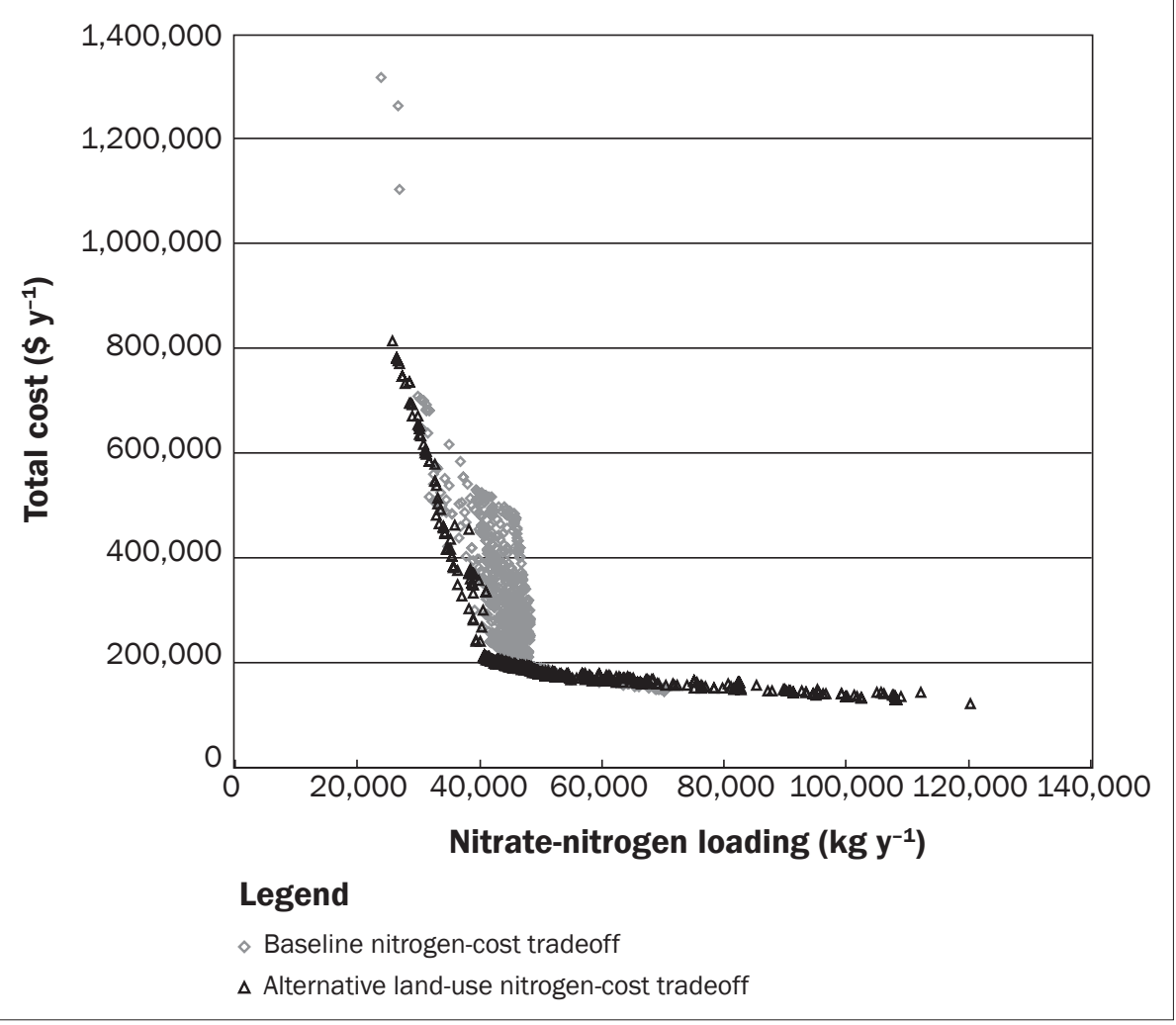

abatement costs, we demonstrate solutions for a range of nutrient reduction targets. We can focus on three types of nutrient targets: $\mathrm{N}$ reductions only, $\mathrm{P}$ reductions only, or a combination of $\mathrm{N}$ and $\mathrm{P}$ reductions. We focus on the third type of targets for this discussion. We start with the baseline land-use results and search for points on the tradeoff frontier that simultaneously reduce $\mathrm{NO}_{3}-\mathrm{N}$ loadings and total $\mathrm{P}$ loadings by $10 \%, 20 \%, 30 \%, 40 \%$, and $50 \%$. We then turn to the alternative land-use tradeoff frontier and search for points that are capable of delivering the same absolute level of nutrient loadings. Table 4 presents the results, as well as the estimated marginal abatement costs at each level of abatement. (Given that it is difficult to select a functional form for the marginal abatement cost curves a priori, we make use of another application of evolutionary algorithms and build the functional forms using a genetic programming algorithm developed by Schmidt and Lipson [2009]).

Under the historical land use, focusing on achieving a $\mathrm{N}$ target leads to a more than proportional reduction in $\mathrm{P}$, while in the alternative land use, focusing on a $\mathrm{P}$ target leads to a more than proportional reduction in N. Although given the enormity of the search space, this cannot be said to be definitive, such findings do highlight an interesting interaction in terms of land use and focus on nutrient reductions. It is thus unlikely that a one-size-fits-all prescription in terms of nutrient targeting could emerge, without careful attention to the watershed circumstances, land use in particular.

For all nutrient reductions targets (except for $50 \%$ ), we find that the alternative land use is detrimental to water quality in the sense that additional investment in conservation practices would be required to achieve any specified nutrient reduction goal.

Spatial Distribution and Mix of Conservation Practices for Selected Watershed Configurations. Table 5 presents the mix and distribution of conservation practices for the individuals (watershed configurations) selected from the baseline land-use tradeoff frontier and the alternative land-use tradeoff frontier. In the baseline land-use tradeoff frontier, as the nutrient targets become more stringent, there is a definite progression from mulch-till to no-till (in interaction with grassed waterways and terraces), and as stringency of nutrient targets rises, so does the use of $\mathrm{N}$ fertilizer reductions and 
Table 4

Individual solutions (watershed configurations) found for a range of nutrient reductions.

\begin{tabular}{|c|c|c|c|c|c|c|}
\hline $\begin{array}{l}\text { Reduction } \\
\text { (\%) }\end{array}$ & $\begin{array}{l}\text { Individual } \\
\text { number in } \\
\text { the tradeoff } \\
\text { frontier }\end{array}$ & $\begin{array}{l}\text { Actual } \\
\text { reduction, } \\
\text { nitrate } \\
(\%) \\
\end{array}$ & $\begin{array}{l}\text { Actual } \\
\text { reduction, } \\
\text { phosphorus } \\
\text { (\%) } \\
\end{array}$ & $\begin{array}{l}\text { Extra cost in } \\
\text { addition to } \\
\text { existing } \\
\text { conservation } \\
\text { practices } \\
\left(\text { dollars } \mathbf{y}^{-1}\right) \\
\end{array}$ & $\begin{array}{l}\text { Implied } \\
\text { marginal } \\
\text { abatement } \\
\text { cost, N/P } \\
\left(\text { dollars kg }{ }^{-1} \text { ) }\right.\end{array}$ & $\begin{array}{l}\text { Extra cost } \\
\text { required due } \\
\text { to land use } \\
\text { change } \\
\left(\text { dollars } y^{-1}\right) \\
\end{array}$ \\
\hline \multicolumn{7}{|c|}{ Baseline land use } \\
\hline 10 & 324 & 10 & 20 & 10,597 & $0.5 / 0.2$ & - \\
\hline 40 & 1,138 & 40 & 60 & 88,805 & $12.7 / 45.0$ & - \\
\hline 50 & 2,320 & 51 & 59 & 275,569 & $42.7 / 45.0$ & - \\
\hline \multicolumn{7}{|c|}{ Alternative land use } \\
\hline 10 & 2,372 & 30 & 10 & 37,345 & $5.2 / 5.3$ & 26,748 \\
\hline 20 & 2,253 & 31 & 20 & 43,917 & $5.7 / 5.6$ & 24,002 \\
\hline
\end{tabular}

Notes: N/P = dollar values for marginal abatement cost for nitrogen and for phosphorus. $-=$ not applicable.

eventually land retirement. (The cost of $\mathrm{N}$ fertilizer reductions in the baseline land-use runs is computed using a high price of corn $\left(\$ 5.9 \mathrm{bu}^{-1}\left[\$ 167.4 \mathrm{~m}^{-3}\right]\right)$ to make the tradeoff frontiers from different land-use patterns comparable. In related work we find that if the cost of fertilizer reductions is lowered, the fertilizer reduction option is selected to a much greater extent.)

In the alternative land-use tradeoff frontier, only four of the 33 available conservation practice combinations are selected: no-till, no-till with contours, no-till with grassed waterways, and no-till with terraces, with the shift toward no-till grassed waterways and notill terraces as the stringency of nutrient targets increases. Practices such as no-till, no-till with terraces, no-till with grassed waterways, and no-till with contours are selected for a greater area of the watershed under the alternative land use across the entire range of nutrient reduction targets. No-till and contours were selected much more frequently under the alternative land use, while grassed waterways are selected more frequently under the baseline land use across the full range of nutrient reduction targets.

The location and the mix of conservation practices selected can be mapped back to the field-level spatial decision-making units in the watershed. Thus, our approach, which specifies a particular mix and distribution of conservation practices, can provide policymakers with tools for better targeting of conservation policy aimed at water quality improvements. In terms of implementation, armed with the algorithm's prescriptions, policymakers can offer targeted payments (method suggested by Khanna et al. [2003]), or elicit bids and accept or reject them using modeling results as guidance. Of course, the specific set of practices targeted depends on particular water quality goals.

To demonstrate, we present two individual solutions (watershed configurations), which reach at least a $30 \%$ reduction in both nitrates and $\mathrm{P}$ (figure 5). For the historical land use, we call such a solution "Historical_N30_P30," and for the alternative land use, we call such a solution "Alternative_N30_P30." Searching the two tradeoff frontiers (and given that each solution is denoted by a unique identification number), we select individual \#1541 as "Historical_N30_P30" solution and individual \#2026 as the "Alternative_N30_P30" solution. Solution \#1541 over-achieves the $\mathrm{P}$ target, reducing $\mathrm{P}$ loadings by $48 \%$, while solution \#2026 over-achieves the $\mathrm{N}$ target, reducing $\mathrm{N}$ by $36 \%$. A reduction of at least a $30 \%$ in both nutrients is costlier to achieve under the alternative land use, with the extra cost estimated to be $\$ 15.3$ thousand $\mathrm{y}^{-1}$.

As expected, land-use changes affect the mix and optimal placement of conservation practices in the watershed, suggesting that watershed managers might need to anticipate future land-use changes in the watershed in their selection and targeting of conservation practices. While the solutions are different, both utilize grassed waterways and terraces as the dominant conservation practices. Also, maps reveal an interesting pattern of location of terraces (highlighted in lavender [when used with no-till] and in purple [when used with mulch-till] in figure 5). There is a distinct set of locations in the watershed selected for terraces. Other solutions also exhibit this finding (maps available upon request). The findings suggest that the watershed may contain areas that are particularly suitable for terracing and that the location of these areas might be invariant to the farmers' choice of crops. Such findings are expected to assist watershed managers in targeting specific watershed areas for water quality protection efforts.

An interesting extension would focus on finding a set of conservation practices that may be robust, or resilient, to future land-use changes. Conceptually, one expects that there exists a tradeoff between the cost of the solution and its robustness. An optimal solution tailored to a particular land use has the lowest cost for that particular land use but is likely to be much less robust in terms of achieving nutrient reductions than a costly solution which, for example, prescribes extensive land retirement. We expect there will be other solutions occupying intermediate positions along the cost and robustness dimension. The problem of finding the efficient frontier may be tackled by modifying the multiobjective problem to strive for simultaneous minimization of the cost and the suitably created robustness score. 
Table 5

Share of cropland under conservation practices, baseline and alternative land use solutions.

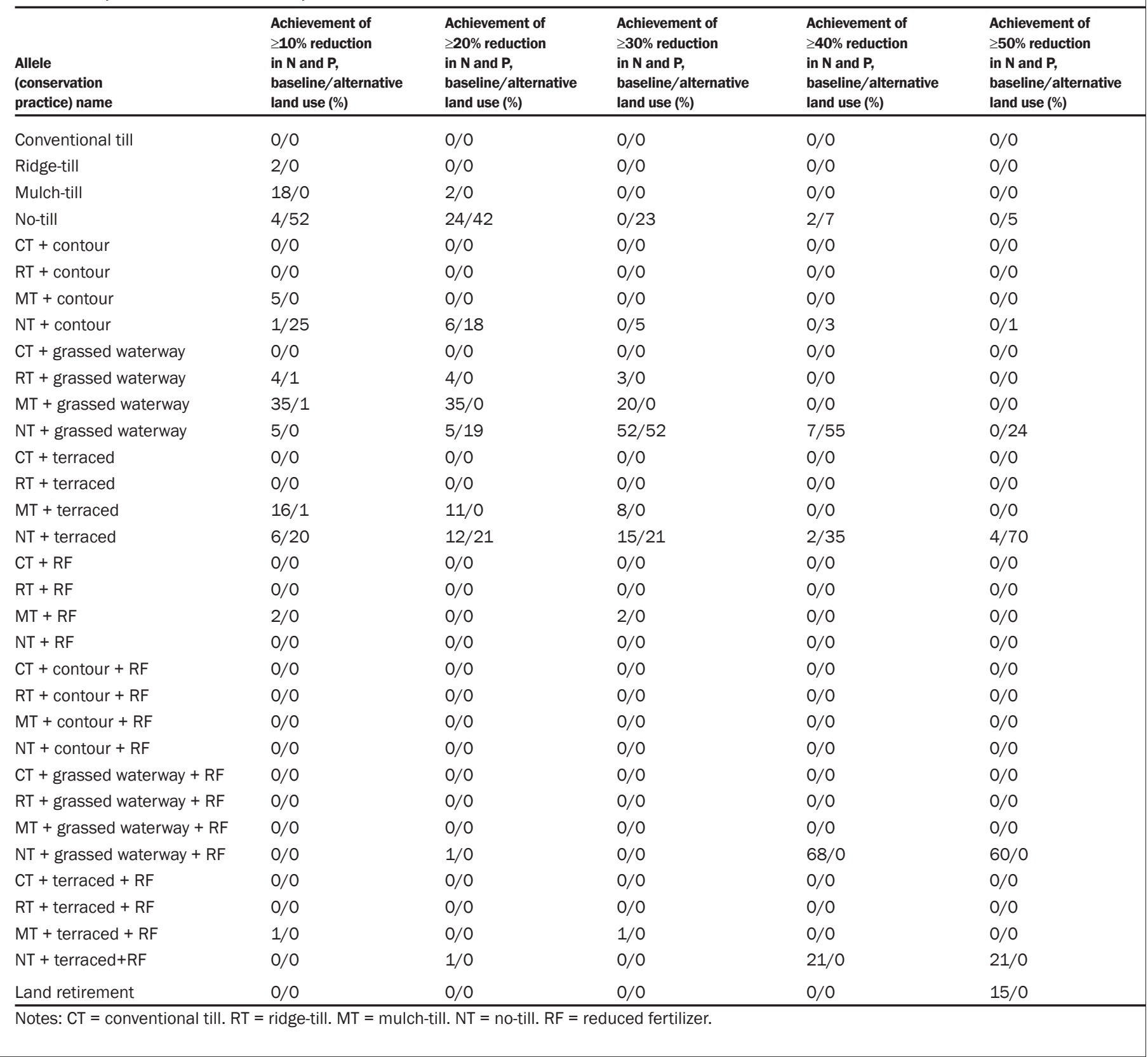

\section{Summary and Conclusions}

We are building an integrated simulation-optimization framework to search for Pareto-efficient sets of watershed configurations involving lowest-cost mix and location of agricultural conservation practices to achieve a range of watershed-level nutrient reduction objectives. Recognizing the importance of farmer decision-making, we are investigating how the efficient tradeoffs might change in the event of significant changes in crop prices and production costs. We apply our methodology to a typi- cal agricultural watershed in central Iowa. We find that the effect of higher prices of corn and soybeans is to shift production to corn-intensive crop rotations, to increase $\mathrm{N}$ fertilizer applications, and to reduce the amount of conservation tillage. In addition, marginal land is brought into crop production. The overall effect on model-simulated measures of water quality is quite negative: both $\mathrm{NO}_{3}-\mathrm{N}$ and total $\mathrm{P}$ loadings are predicted to increase dramatically.

In addition, we find that the mix and location of conservation practices to be placed on the landscape in a cost-efficient fashion depends, predictably, on the land use prevailing in the watershed. We find that for a wide range of nutrient reduction targets, a shift to more corn production may require a different mix of conservation practices, as well as additional investment in order to achieve nutrient reduction goals, which were feasible under the historically prevailing land use. Interestingly, the selection of conservation practice options involving terraces remains virtually unchanged in the baseline and the alternative use scenarios for a wide 


\section{Figure 5}

Solutions achieving at least a $30 \%$ reduction in both nutrients from historical land-use baselines: (a) "Historical_N30_P30" (solution \#1541) (30\% nitrate reduction, $48 \%$ total phosporus reduction), (b) “Alternative_N30_P30" (solution \#2026) (36\% nitrate reduction, 30\% total phosphorus reduction).

(a)

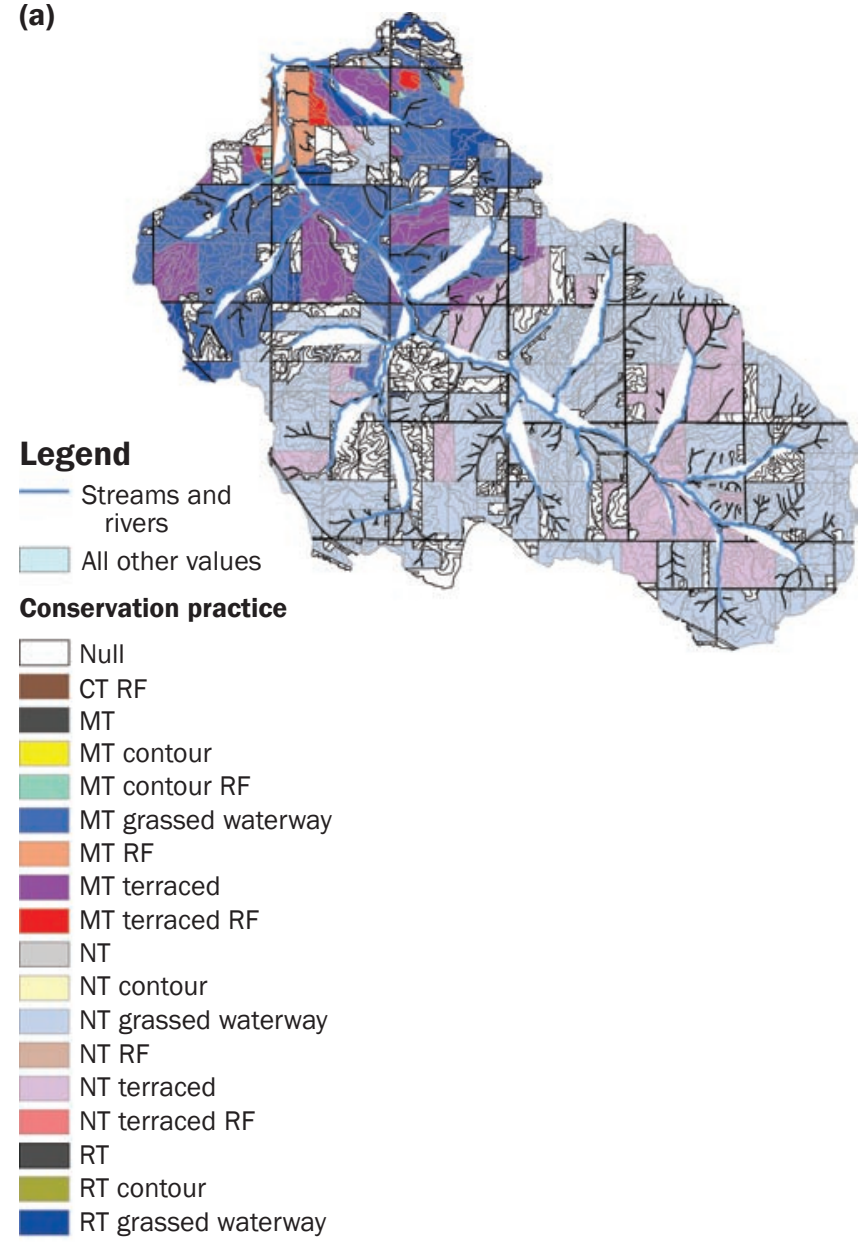

(b)

Legend Streams and
rivers

All other values

Conservation practice

Null

MT grassed waterway

NT

NT contour

NT grassed waterway

NT terraced

RT grassed waterway range of nutrient reduction targets. This suggests that for this particular watershed, a set of practices selected under the historical land use and cropping patterns could be easily modified to remain a cost-efficient solution should cropping patterns change. This is suggestive of a potential to develop a set of optimal conservation practices, which are resilient to changes in cropping practices (or other external factors). This would present important policy implications for targeting investments in water quality improvements, as certain areas and practices could be selected with some confidence that future farmer behavior would not necessitate a drastic realignment of conservation practice investments. Clearly, care must be exercised in generalizing the results obtained to other potential land-use scenarios or other water- sheds. However, future improvements in the hydrologic model and the economic cost estimates can readily be incorporated into the simulation-optimization system. The framework developed is readily generalizable and is capable of providing useful and policyrelevant insight into a complex problem of nonpoint source pollution reductions.

\section{References}

Arabi, M., J. Frankenberger, B. Engel, and J. Arnold 2007. Representation of agricultural management practices with SWAT. Hydrological Processes, doi:10.1002/hyp.6890.

Arabi, M., R.S. Govindaraju, and M.M. Hantush. 2006. Costeffective allocation of watershed management practices using a genetic algorithm. Water Resources Research 42:W10429, doi:10.1029/2006WR004931.

Arnold, J.G., and P.M. Allen. 1999. Automated methods for estimating baseflow and groundwater recharge from streamflow record. Journal of American Water Resources Association 35(2):411-424

Arnold, J.G., and N. Fohrer. 2005. Current capabilities and research opportunities in applied watershed modeling. Hydrological Processes 19:563-572.

Arnold, J.G., R. Srinivasan, R.S. Muttiah, and J.R. Williams. 1998. Large area hydrologic modeling and assessment part I: Model development. Journal of American Water Resources Association 34(1):73-89.

Bekele, E.G., and J.W. Nicklow. 2005. Multiobjective management of ecosystem services by integrative watershed modeling and evolutionary algorithms. Water Resources Research 41:W10406, doi:10.1029/2005WR004090.

Borah, D.K., and M. Bera. 2004. Watershed-scale hydrologic and nonpoint-source pollution models: Review of applications. Transactions of the American Society of Agricultural Engineers 47(3):789-803

Braden, J.B., G.V. Johnson, A. Bouzaher, and D. Miltz. 1989. Optimal spatial management of agricultural pollution. American Journal of Agricultural Economics 61:404-13. Carpentier, C.L., D.J. Bosch, and S.S. Batie. 1998. Using spatial information to reduce costs of controlling 
agricultural nonpoint source pollution. American Journal of Agricultural Economics 61:404-413.

CARD (Center for Agricultural and Rural Development). 2007. CARD Interactive Software Programs. Ames, IA: Center for Agricultural and Rural Development Iowa State University. http://www.card.iastate.edu/ environment/interactive_programs.aspx.

Cooper, J.C., and R.W. Keim. 1996. Incentive Payments to Encourage Farmer Adoption of Water Quality Protection Practices. American Journal of Agricultural Economics 78:54-64.

Deb, K. 2001. Multi-objective Optimization Using Evolutionary Algorithms. Hoboken:Wiley.

De Jong, K.A. 2006. Evolutionary Computation: A Unified Approach. The MIT Press: Cambridge.

Edwards, W., and D. Smith. 2007. Cash rental rates for Iowa 2007 survey. Iowa State University Extension, Ag Decision Maker, File C2-10.

FAPRI (Food and Agricultural Policy Research Institute). 2007. FAPRI 2007 U.S. and World Agricultural Outlook. FAPRI Publications 07-fsr1, Food and Agricultural Policy Research Institute (FAPRI) at Iowa State University. http://www.card.iastate.edu/publications/ synopsis.aspx?id=1047.

Forrest, S. 1993. Genetic algorithms: Principles of natural selection applied to computation. Science 261:872-878.

Gassman, P.W., T. Campbell, S. Secchi, M. Jha, and J.G. Arnold. 2003. The i_SWAT software package: A tool for supporting SWAT watershed applications. In SWAT2003: The 2nd International SWAT Conference, 66-69. July 1-4. Bari, Italy. Bari, Italy: Instituto di Ricerca sulle Acque, IRSACNR.

Gassman, P.W., M. Reyes, C.H. Green, and J.G. Arnold 2007. The Soil and Water Assessment Tool: Historical development, applications, and future directions. Transactions of the American Society of Agricultural and Biological Engineers 50(4):1211-1250.

Gassman, P.W., A. Saleh, E. Osei, J. Abraham, and J. Rodecap. 2003. Environmental and economic impacts of alternative management scenarios for the Mineral Creek Watershed. Proceedings of the Total maximum Daily Load (TMDL) Environmental Regulations II, 323-331. November 812, Albuquerque, New Mexico. St. Joseph, MI:American Society of Agricultural Engineers.

Hu, X., G.F. McIssac, M.B. David, and C.A.L. Louwers. 2007. Modeling riverine nitrate export from an eastcentral Illinois watershed using SWAT: Journal of Environmental Quality 36:996-1005.

ISU (Iowa State University). 2009. Iowa Environmental Mesonet:National Weather Service Cooperative Observer Program. Ames, IA: Iowa State University Department of Agronomy. http://mesonet.agron.iastate.edu/COOP/.

Jayakrishnan, R., R. Srinivasan, C. Santhi, and J.G. Arnold. 2005. Advances in the application of the SWAT model for water resources management. Hydrologic Processes 19(3):749-762.

Jha, M., S. Rabotyagov, and P.W. Gassman. Forthcoming. Optimal placement of conservation practices using genetic algorithm with SWAT. International Agricultural Engineering Journal.

Jha, M.K., K.E. Schilling, P.W. Gassman, and C.F. Wolter. 2010. Targeting land-use change for nitrate-nitrogen load reductions in an agricultural watershed. Journal of Soil and Water Conservation 65(6):342-352, doi:10.2489/jswc.65.6.342.

Khanna, M., W.Yang, R. Farnsworth, and H. Onal. 2003. Cost effective targeting of CREP to improve water quality with endogenous sediment deposition coefficients. American Journal of Agricultural Economics 85:538-53.
Kling, C., S. Secchi, M. Jha, L. Kurkalova, H.F. Hennessy, and P.W. Gassman. 2005. Nonpoint source needs assessment for Iowa: The cost of improving Iowa's water quality. Final Report to the Iowa Department of Natural Resources. Ames, IA: Iowa State University Center for Agricultural and Rural Development.

Kling, C.L., S. Rabotyagov, M. Jha, H. Feng, J. Parcel, P. Gassman, and T. Campbell. 2007. Conservation practices in Iowa: Historical investments, water quality and gaps. Final Report. Ames, IA: Iowa State University Center for Agricultural and Rural Development.

Kramer, R.A., W.T. McSweeny, W.R. Kerns, and R.W Stravros. 1984. An evaluation of alternative policie for controlling agricultural nonpoint source pollution. Water Resources Bulletin 20:841-46.

Kurkalova, L.A., C. Kling, and J. Zhao. 2006. Green subsidies in agriculture: Estimating the adoption costs of conservation tillage from observed behavior. Canadian Journal of Agricultural Economics 54:247-267.

Lant, C.L., S.E. Kraft, J. Beaulieu, D. Bennett, T. Loftus, and J. Nicklow. 2005. Using GIS-based ecological-economic modeling to evaluate policies affecting agricultural watersheds. Ecological Economics 55:467- 484.

Lichtenberg, E. 2004. Cost-responsiveness of conservation practice adoption: A revealed preference approach. Journal of Agricultural and Resource Economics 29:420-435

Mitchell, M. 1996. An introduction to genetic algorithms. Cambridge, Massachusetts: The MIT Press.

Montgomery, W.D. 1972. Markets in licenses and efficient pollution control programs. Journal of Economic Theory 5:395-418.

Muleta,M.K., and J.W.Nicklow.2002.Evolutionary algorithms for multiobjective evaluation of watershed management decisions. Journal of Hydroinformatics 4(2):83-97.

Muleta, M.K., and J.W. Nicklow. 2005. Decision support for watershed management using evolutionary algorithms. Journal of Water Resources Planning and Management 131(1):35-44.

Rabotyagov, S.S., T. Campbell, M.Jha, P.W. Gassman,J.Arnold, L. Kurkalova, S. Secchi, H. Feng, and C.L. Kling. 2010 Least-cost control of agricultural nutrient contributions to the Gulf of Mexico hypoxic zone. Ecological Applications 20(6):1542-1555, doi:10.1890/08-0680.1.

Ribaudo,M.O.1986.Consideration of off-site impacts in targeting soil conservation programs. Land Economics 62:402-11.

Ribaudo, M.O. 1989. Targeting the conservation reserve program to maximize water quality benefits. Land Economics 65:320-32.

Richards, R.P., and D.B. Baker. 2002. Trends in water quality in LEASEQ rivers and streams (northwestern Ohio), 197501995: Journal of Environmental Quality 31:90-96.

Rudolph, G., and A. Agapie. 2000. Convergence properties of some multi-objective evolutionary algorithms. In Proceedings of the Congress on Evolutionary Computation (CEC-2000), 1010-1016.

Sawyer, J., E. Nafziger, G. Randall, L. Bundy, G. Rehm, and B. Joern. 2006. Concepts and rational for regional nitrogen rate guidelines for corn. Ames, IA: Iowa State University. http://extension.agron.iastate.edu/soilfertility/nrate.aspx.

Schilling, K.E., T. Hubbard, J. Luzier, and J. Spooner. 2006 Walnut Creek Watershed Restoration and Water Quality Monitoring Project: Final Report. Iowa Geological Survey Technical Information Series 49.

Schmidt M., and H. Lipson. 2009. Distilling Free-Form Natural Laws from Experimental Data. Science 324(5923):81-85.

Secchi S., and B.A. Babcock. 2007. Impact of High Crop Prices on Environmental Quality:A Case of Iowa and the Conservation Reserve Program. Working Paper 07-WP
447. Center for Agricultural and Rural Development. Ames, IA: Iowa State University.

Secchi, S., P.W. Gassman, M. Jha, H.H. Feng, T. Campbell, and C.L. Kling. 2007. The cost of cleaner water: Assessing agricultural pollution reduction at the watershed scale. Journal of Soil and Water Conservation 62(1):10-21.

Secchi, S., M. Jha, L.A. Kurkalova, H. Feng, P.W. Gassman, and C.L. Kling. 2005. The designation of co-benefits and its implication for policy: Water quality versus carbon sequestration in agricultural soils. CARD Working Paper 05-WP 389, Ames, IA: Iowa State University.

Srivastava, P., J.M. Hamlett, P.D. Robillard, and R.L. Day. 2002. Watershed optimization of best management practices using AnnAGNPS and a genetic algorithm. Water Resources Research 38(3):1-14.

Tan, K.C., E.F. Khor, and T.H. Lee. 2005. Multiobjective evolutionary algorithms and applications. SpringerVerlag, London.

USDA NRCS (National Resources Conservation Service). 2007. State-Level Costs for Conservation Practices. http:// www.economics.nrcs.usda.gov/cost/nrcscost.html.

USDA NRCS. 2008. Soil Survey Geographic (SSURGO) Database. Washington DC: USDA Natural Resources Conservation Service. http://www.soils.usda. gov/survey/geography/ssurgo/.

USGS (US Geological Survey). 2008a. The National Map Seamless Server. Reston, VA: US Geological Survey. http://seamless.usgs.gov/.

Vache, K.B., J.M. Eilers, and M.V. Santelman. 2002. Water quality modeling of alternative agricultural scenario in the U.S. corn belt. Journal of the American Water Resources Association 38(2):773-787.

Veith, T.L., M.L. Wolfe, and C.D. Heatwole. 2003 Development of optimization procedure for costeffective BMP placement. Journal of the American Water Resources Association 39(6):1331-1343

Veith, T.L., M.L. Wolfe, and C.D. Heatwole. 2004. Costeffective BMP placement: Optimization versus targeting. Transactions of the American Society of Agricultural Engineers 47(5):1585-1594.

Wall, M. 1996. GAlib: A C++ Library of Genetic Algorithm Components.Version 2.4.6. http://lancet.mit.edu/ga/.

Whittaker, G., Jr., R. Confesor, S.M. Griffith, R. Färe, S Grosskopf, J.J. Steiner, G.W. Mueller-Warrant, and G.M. Banowetz. 2007. A Hybrid Genetic Algorithm for Multiobjective Problems with Activity Analysis-based Local Search. European Journal of Operaional Research, doi:10.1016/j.ejor.2007.10.050.

Zitzler, E., M. Laumanns, and L. Thiele. 2002. SPEA2 Improving the Strength Pareto Evolutionary Algorithm for Multiobjective Optimization. Evolutionary Methods for Design, Optimisation, and Control, 95-100. Barcelona, Spain: CIMNE. 